\title{
The microbiome of the skin
}

\author{
Mikrobiom skóry
}

Katarzyna Adamczyk, Agnieszka A. Garncarczyk, Paweł P. Antończak

Department of Cosmetology, Chair of Cosmetology, School of Pharmacy with Division of Laboratory Medicine in Sosnowiec, Medical University of Silesia in Katowice, Poland

Zakład Kosmetologii Katedry Kosmetologii Wydziału Farmaceutycznego z Oddziałem Medycyny Laboratoryjnej w Sosnowcu, Śląski Uniwersytet Medyczny w Katowicach, Polska

\author{
CORRESPONDING AUTHOR/ \\ ADRES DO KORESPONDENCJI: \\ dr n. med. Katarzyna Adamczyk \\ Zakład Kosmetologii \\ Katedry Kosmetologii \\ Wydział Farmaceutyczny \\ z Oddziałem Medycyny \\ Laboratoryjnej w Sosnowcu \\ Śląski Uniwersytet \\ Medyczny w Katowicach \\ ul. Kasztanowa 3 \\ 41-200 Sosnowiec, Polska \\ e-mail: kadamczyk@sum.edu.pl
}

\begin{abstract}
Skin is the most external organ of the body, protecting it from environmental factors. The barrier functions of the skin are significantly supported by the cutaneous microbiome (bacteria, fungi, mites and viruses). To perform its functions, the microbiome must have a certain size and diversity. The microbiome balance can be disrupted by internal and environmental factors. Disturbed homoeostasis is observed, among other conditions, in the course of atopic dermatitis, psoriasis, acne vulgaris, rosacea, and seborrhoeic dermatitis. The skin is inhabited primarily by four phyla of bacteria: Actinobacteria, Firmicutes, Bacteroidetes and Proteobacteria. The dominant fungal and mite species residing on the skin are lipophilic fungi of the genus Malassezia and Demodex, respectively. Viruses are an unstable but essential element of the skin microbiome, particularly viruses containing double stranded DNA (dsDNA) such as Polyomaviridae and Papillomaviridae.
\end{abstract}

\section{STRESZCZENIE}

Skóra jest najbardziej zewnętrznym organem ciała, który stanowi ochronę przed czynnikami środowiskowymi. Barierowe funkcje skóry są istotnie wspierane przez jej mikrobiom (bakterie, grzyby, roztocza i wirusy). Mikrobiom, by pełnił swoje funkcje, musi charakteryzować się określoną wielkością i różnorodnością. Czynniki wewnętrzne i środowiskowe mogą zaburzać równowagę mikrobiomu. Zaburzoną homeostazę obserwuje się w przebiegu m.in. atopowego zapalenia skóry, łuszczycy, trądziku pospolitego, trądziku różowatego i łojotokowego zapalenia skóry. Skóra zasiedlana jest głównie przez cztery typy bakterii: Actinobacteria, Firmicutes, Bacteroidetes i Proteobacteria. Najważniejszymi gatunkami grzybów zasiedlających skórę są lipofilne grzyby z rodzaju Malassezia, a roztoczy - nużeńce (Demodex). Wirusy stanowią niestały, ale istotny element mikrobiomu skóry, zwłaszcza wirusy zawierające dwuniciowe DNA (dsDNA), takie jak poliomawirusy (Polyomaviridae) i papillomawirusy (Papillomaviridae).

Key words: microbiome, physiological skin flora, dysbiosis.

Słowa kluczowe: mikrobiom, fizjologiczna flora skóry, dysbioza. 


\section{MICROBIOME (MICROBIOTA)}

The term "microbiome" (or "microbiota") refers to the sum total of microorganisms in a particular habitat. The human body as a microbial habitat is a complex group of ecosystems inhabited by microorganisms representing diverse species. Sites colonized by microbiota include the oral cavity, digestive tract, airways, genitourinary system and skin. The skin is the body's most external organ, consisting of areas with varying epidermal thickness, location of skin appendages, and levels of moisture and temperature on the surface. These qualities have a significant effect on the microflora in terms of species composition and quantitative distribution. The skin is inhabited by bacteria, fungi, viruses and mites. The majority of skin-colonizing microorganisms are harmless and live in a symbiotic relationship with the skin cells. However, interactions between constituents of the microbiota and skin cells are complex and include mutualism, parasitism and commensalism [1-3].

The species composition of the skin microbiome has not been fully elucidated. Gaps in the knowledge of skin-resident microorganisms are due to limited diagnostic capabilities. Standard cultures and isolation of bacterial strains from clinical samples harvested from patients suffer from a number of limitations. In vitro microbial growth is determined by the sample-taking technique and type of transport medium used, culture conditions and medium, and the initial species composition of the cultured material (since different bacterial and fungal species grow in cultures at varying rates, one of the species cultured often displaces slower growing microorganisms). Also, the majority of skin-resident microbes are not culturable in laboratory conditions. The possibility to apply molecular methods based on nucleic acid analysis - such as the sequencing of the highly conserved region $16 \mathrm{~S}$ rRNA in bacteria and whole sequencing of genetic material samples harvested from various ecological niches (metagenomics) - gradually expands the knowledge of the skin microbiome [4-6].

\section{SKIN AS A MICROBIAL HABITAT}

The skin is the largest organ in the human body. The primary functions of the skin include integration of the body with the external environment and, at the same time, its protection from environmental factors. With respect to structure and biology, the skin is an extremely hostile environment for microbial growth. The epidermal surface is, for the most part, dry and rough, and constantly exfoliating. Since microorganisms are removed from the skin on a regular basis, they have no possibilities for unlimited growth and formation of biofilm on the skin

\section{MIKROBIOM (MIKROBIOTA)}

Termin mikrobiom (mikrobiota) określa ogół mikroorganizmów występujących w danym siedlisku. Organizm ludzki jako siedlisko drobnoustrojów stanowi złożony zespół ekosystemów z odrębnymi gatunkowo mikroorganizmami. Do zasiedlanych stanowisk zalicza się: jamę ustną, przewód pokarmowy, drogi oddechowe, układ moczowo-płciowy oraz skórę. Skóra stanowi najbardziej zewnętrzny organ naszego ciała, jej poszczególne obszary różnią się pod względem grubości naskórka, rozmieszczenia przydatków oraz wilgotności $i$ temperatury na powierzchni. Cechy te istotnie wpływają na skład gatunkowy i ilościowy mikroflory. Skóra jest zasiedlana przez bakterie, grzyby, wirusy i roztocza. Większość mikroorganizmów zasiedlających skórę jest nieszkodliwa i funkcjonuje w symbiozie z komórkami skóry. Interakcje między mikrobiontami a komórkami skóry są jednak złożone i obejmują mutualizm, pasożytnictwo i komensalizm [1-3].

Skład gatunkowy mikrobiomu skóry nie został w pełni poznany. Przyczyną niepełnej wiedzy na temat drobnoustrojów zasiedlających skórę są możliwości diagnostyczne. Standardowo stosowane hodowle i izolacja szczepów bakterii z materiałów klinicznych pochodzących od pacjentów mają wiele ograniczeń. Na wzrost drobnoustrojów w warunkach in vitro wpływa technika pobrania materiału i rodzaj zastosowanego podłoża transportowego, warunki hodowli i rodzaj podłoża hodowlanego oraz wyjściowy skład gatunkowy materiału (poszczególne gatunki bakterii i grzybów rosną w hodowlach $\mathrm{z}$ różną prędkością $\mathrm{i}$ często jeden $\mathrm{z}$ hodowanych gatunków wypiera te wolniej rosnące). Wiadomo również, że większości drobnoustrojów bytujących na powierzchni skóry nie hoduje się w warunkach laboratoryjnych. Możliwość zastosowania metod molekularnych opartych na analizie kwasów nukleinowych, takich jak analiza sekwencji wysoce konserwatywnego regionu $16 \mathrm{~S}$ rRNA bakterii oraz całościowe sekwencjonowanie próbek materiału genetycznego pobranego z różnych nisz ekologicznych (metagenomika), stopniowo poszerza wiedzę na temat mikrobiomu skóry [4-6].

\section{SKÓRA JAKO ŚRODOWISKO BYTOWANIA DROBNOUSTROJÓW}

Skóra stanowi największy narząd ciała człowieka, którego podstawową czynnością jest integracja organizmu ze środowiskiem zewnętrznym i jednocześnie jego ochrona przed czynnikami środowiskowymi. Pod względem budowy i biologii stanowi wyjątkowo nieprzyjazne siedlisko dla wzrostu mikroorganizmów. Powierzchnia naskórka na znacznej części jest sucha, szorstka i ciągle się złuszcza. Drobnoustroje są regularnie usuwane z powierzchni skóry, więc nie mają możliwości nieograniczonego wzrostu i tworzenia na powierzchni skóry 
surface $[1,4]$. Microbial growth is further inhibited by the skin's hydrolipid film which makes the environment acidic ( $\mathrm{pH}$ between 4 and 6.5) and contains compounds with antibacterial effects (dermcidin, lysozyme, sebum) $[4,7,8]$. The ability to produce antimicrobial compounds has been shown in keratinocytes, sebocytes, sweat gland cells and mastocytes. More than 20 antimicrobial peptides (AMPs) have been identified on the skin surface, including cathelicidin (LL-37), defensins: defensin $\beta 1$ (HBD1), HBD2, HBD3, psoriasins, antimicrobial protein RNase 7 (SAP-2) and protein SLPI. On account of such living conditions the skin may be colonized only by specific microbial species. Furthermore, these conditions have a significant effect on microbial counts. Consequently, the skin microbiome is resistant to changes and stable in terms of its composition and count $[4,9]$.

\section{SKIN MICROBIOME COMPOSITION}

\section{Skin-inhabiting bacteria}

The human skin is inhabited primarily by four phyla of bacteria: Actinobacteria (Corynebacterium spp., Propionibacterium spp., Microbacterium spp., Micrococcus spp.), Firmicutes (non-haemolytic aerobic and anaerobic staphylococci (Staphylococcus spp.), Clostridium spp., $\alpha$-haemolytic streptococci (Streptococcus spp.) and enterococci (Enterococcus), Bacteroidetes (Sphingobacterium spp., Chryseobacterium spp.), as well as Proteobacteria (Janthinobacterium spp., Serratia spp., Halomonas spp., Delftia spp., Comamonas spp.) [1, 10-12].

It is estimated that $50 \%$ of all skin-resident bacteria belong to the species $S$. epidermidis inhabiting upper part of hair follicule. Other bacterial species living on the skin surface include $S$. saprophyticus, S. hominis, S. warneri, S. haemolyticus and S. capitis. The dominant bacterial species of the genera Corynebacterium and Propionibacterium are C. jeikeium and P. acnes, respectively. Members of the bacterial genus Micrococcus isolated from the skin surface include $M$. luteus and, less commonly, $M$. varians, M. lylae, $M$. sedentarius, $M$. roseus, M. kristinae and M. nishinomiyaensis [4]. The bacteria belong to symbiotic species and represent the most stable element of the skin microbiome. The percentage proportions of other bacterial species are much lower, and some of them represent the variable component of the microbiome. However, the bacteria play an essential role for maintaining equilibrium in the quantitative and qualitative composition of the microbiome by affecting the growth of other microorganisms $[1,13]$.

The human skin may also be colonized by pathogenic bacteria including $S$. aureus, group A streptococci (S. pyogenes), aerobic corynebacteria (Corynebacterium spp.) and Gram-negative bacilli ( $P$. aeruginosa). The biofilmu [1, 4]. Wzrost drobnoustrojów na powierzchni skóry utrudnia dodatkowo obecność płaszcza hydrolipidowego, który zakwasza środowisko do $\mathrm{pH}$ od 4 do 6,5 oraz zawiera związki o działaniu przeciwbakteryjnym (dermicydyna, lizozym, sebum) [4, 7, 8]. Zdolność wydzielania czynników przeciwdrobnoustrojowych mają keratynocyty, sebocyty, komórki gruczołów potowych i komórki tuczne. Wykazano, że na powierzchni skóry występuje ponad 20 peptydów o działaniu przeciwbakteryjnym (antimicrobial peptides - AMPs). Są to m.in.: katelicydyna (LL-37), defensyny - defensyna $\beta 1$ (HBD1), HBD2, HBD3, psoriazyny, przeciwdrobnoustrojowe białko RNaza 7 (SAP-2) i białko SLPI. Takie warunki powodują, że skóra może być zasiedlana tylko przez określone gatunki drobnoustrojów. Ponadto warunki te istotnie wpływają na liczebność drobnoustrojów. Mikrobiom skóry jest zatem oporny na zmiany i stabilny pod względem składu i liczebności [4, 9].

\section{SKŁAD MIKROBIOMU SKÓRY}

\section{Bakterie zasiedlające skórę}

Skóra człowieka zasiedlana jest głównie przez cztery typy bakterii: Actinobacteria (Corynebacterium spp., Propionibacterium spp., Microbacterium spp., Micrococcus spp.), Firmicutes (niehemolityczne tlenowe i beztlenowe gronkowce (Staphylococcus spp.), Clostridium spp., $\alpha$-hemolityczne paciorkowce (Streptococcus spp.) i enterokoki (Enterococcus), Bacteroidetes (Sphingobacterium spp., Chryseobacterium spp.) i Proteobacteria (Janthinobacterium spp., Serratia spp., Halomonas spp., Delftia spp., Comamonas spp.) [1, 10-12].

Szacuje się, że $50 \%$ bakterii bytujących na skórze to S. epidermidis zasiedlający wyższe obszary ujść mieszków włosowych. Na powierzchni skóry bytują także S. saprophyticus, S. hominis, S. warneri, S. haemolyticus i $S$. capitis. Głównym gatunkiem bakterii z rodzaju Corynebacterium jest C. jeikeium, a Propionibacterium - P. acnes. Izolowane z powierzchni skóry bakterie z rodzaju Micrococcus to: M. luteus oraz mniej licznie występujące $M$. varians, $M$. lylae, $M$. sedentarius, M. roseus, M. kristinae i M. nishinomiyaensis [4]. Bakterie te należą do gatunków symbiotycznych i stanowią najbardziej stabilny element mikrobiomu skóry. Procentowy udział pozostałych gatunków bakterii jest znacznie niższy, część z nich stanowi też zmienny element mikrobiomu. Bakterie te odgrywają jednak zasadniczą rolę w utrzymaniu równowagi w składzie ilościowym i jakościowym mikrobiomu, gdyż warunkują wzrost innych drobnoustrojów [1, 13].

Skóra człowieka może być zasiedlana także przez bakterie patogenne, takie jak gronkowiec złocisty (S. aureus), paciorkowce grupy A (S. pyogenes), tlenowe maczugowce (Corynebacterium spp.) i pałeczki Gram-ujemne ( $P$. aeruginosa). Bakterie te stanowią 
bacteria are undesirable microflora potentially causing skin infections. On account of the presence of native microflora, bacterial multiplication on the skin surface is difficult, and infections occur only in disturbed physicochemical conditions, immune deficiency, during antibiotic treatment, epidermal discontinuity or presence of foreign bodies (i.e. catheters, artificial valves). The factors listed above can also beneficially affect the growth of bacteria belonging to the physiological skin microflora which, in the enumerated cases, may also prove detrimental to human health [14].

\section{Skin-inhabiting fungi}

The dominant fungal species residing on the skin are lipophilic fungi of the genus Malassezia which make up between $1 \%$ and $22 \%$ of the human microbiome. The genus Malassezia consists of 14 species, of which 9 are capable of colonizing human skin: $M$. furfur, M. sympodialis, M. globosa, M. restricta, M. slooffiae, M. yamatoensis, M. obtusa, M. dermatis and M. japonica $[10,15,16]$.

The dominant species are $M$. globosa and M. restricta [15]. Other Malassezia species are found on the skin in smaller amounts. In favourable conditions Malassezia fungi (particularly M. globosa and M. sympodialis) have a propensity to cause cutaneous diseases, and in cases of marked immune deficiency they may - similarly to bacteria - play a role in systemic infections. The most common diseases caused by fungi of the genus Malassezia are pityriasis versicolor and folliculitis. The fungi also impact the course of dermatitis seborrhoica, psoriasis and atopic dermatitis $[15,17,18]$.

The human skin is also colonized by fungi of the genera Penicillum (P. chrysogenum, P. lanosum), Aspergillus (A. candidus, A. terreus, A. versicolor) and to a lesser extent by Alternaria, Candida (C. tropicalis, C. parapsilosis, C. orthopsilosis), Chaetomium, Chrysosporium, Cladosporium, Mucor, Debaryomyces, Cryptococcus (C. flavus, C. dimmennae, C. diffluent), Trichophyton and Rhodotorula [10]. The yeast C. albicans and fungi of the genus Cryptococcus are capable of colonizing the skin in favourable conditions (damaged epidermal surface, elevated moisture and temperature levels, occlusion) and cause candidiasis and cryptococcosis, respectively. Pathogenic fungi with a potential to induce skin diseases include dermatophytes (Microsporum, Epidermophyton, Trichophyton) [10, 19].

\section{Skin-inhabiting mites}

In addition to bacteria and fungi, the skin microbiota also contains Demodex - parasitic arachnids of the Acari order which inhabit hair follicles and sebaceous glands. Representatives of the physiological microflora of the skin include florę niepożądaną, która może powodować zakażenia skóry. Ze względu na obecność rodzimej mikroflory namnażanie tych bakterii na powierzchni skóry jest utrudnione i do zakażeń dochodzi jedynie w przypadku zaburzenia warunków fizykochemicznych, w stanach niedoboru immunologicznego, leczenia antybiotykami, przerwania ciągłości skóry czy obecności ciał obcych (tj. cewniki, sztuczne zastawki). Wymienione czynniki mogą również nasilać wzrost bakterii wchodzących w skład mikroflory fizjologicznej, która w wymienionych przypadkach może także okazać się groźna dla zdrowia człowieka [14].

\section{Grzyby zasiedlające skórę}

Dominującymi gatunkami grzybów zasiedlających skórę są lipofilne grzyby z rodzaju Malassezia, które stanowią od 1\% do 22\% mikrobiomu człowieka. Rodzaj Malassezia obejmuje 14 gatunków, z czego 9 może kolonizować ludzką skórę: $M$. furfur, M. sympodialis, M. globosa, M. restricta, M. slooffiae, M. yamatoensis, M. obtusa, M. dermatis i $M$. japonica $[10,15,16]$.

Gatunkami dominującymi są M. globosa i M. restricta [15]. Inne gatunki Malassezia występują na skórze w mniejszej ilości. W sprzyjających warunkach $M a-$ lassezia (zwłaszcza M. globosa i M. sympodialis) moga powodować choroby dermatologiczne, a w przypadku znacznego obniżenia odporności mogą się przyczyniać, podobnie jak bakterie, do zakażeń ogólnoustrojowych. Do najczęstszych chorób wywoływanych przez grzyby z rodzaju Malassezia należą łupież pstry (pityriasis vericolor) i zapalenie mieszków włosowych (folliculitis). Grzyby te wpływają także na przebieg łojotokowego zapalenia skóry (dermatitis seborrhoica), łuszczycy (psoriasis) i atopowego zapalenia skóry (atopic dermatitis) $[15,17,18]$.

Skóra człowieka jest również kolonizowana przez grzyby z rodzaju Penicillum (P. chrysogenum, P. lanosum), Aspergillus (A. candidus, A. terreus, A. versicolor) i w mniejszym stopniu przez Alternaria, Candida (C. tropicalis, C. parapsilosis, C. orthopsilosis), Chaetomium, Chrysosporium, Cladosporium, Mucor, Debaryomyces, Cryptococcus (C. flavus, C. dimmennae, C. diffluent), Trichophyton i Rhodotorula [10]. Drożdżaki C. albicans i grzyby z rodzaju Cryptococcus mogą kolonizować skórę w sprzyjających warunkach (uszkodzenie powierzchni naskórka, zwiększona wilgotność i temperatura oraz okluzja) i powodować odpowiednio drożdżycę i cryptococcosis. Patogennymi grzybami zdolnymi do wywoływania chorób skóry są dermatofity (Microsporum, Epidermophyton, Trichophyton) $[10,19]$.

\section{Roztocza zasiedlające skórę}

Poza bakteriami i grzybami w skład mikrobioty skóry wchodzą nużeńce (Demodex), czyli pasożytnicze pajęczaki z rzędu roztoczy, które zasiedlają mieszki wło- 
D. folliculorum (residing in hair follicles) and D. brevis (inhabiting sebaceous and Meibomian glands) [20, 21]. Excessive growth of colonies of Demodex and associated bacteria (Demodex microbiota) is a cause of demodicosis, and probably plays a role in the aetiology and course of rosacea $[1,20,22]$.

\section{Viruses}

The isolation and identification of viruses found on the skin surface is a challenge. Viruses vary in their genetic material (DNA and RNA viruses) and undergo rapid evolution, which makes it more difficult to create genomic libraries. Also, viruses do not have conserved regions which are present in bacterial or fungal genomes (16S rRNA and ITS, respectively). Viruses are believed to be not only pathogenic agents but also factors contributing to the maintenance of skin homoeostasis [5]. Viruses are known to be an unstable, though essential, component of the skin microbiome, particularly viruses containing double-stranded DNA (dsDNA) such as Polyomaviridae and Papillomaviridae [9, 14].

\section{MICROBIAL NICHES ON THE SKIN SURFACE}

The qualitative composition of the human microbiome is specific to the individual and varies depending on the skin site. Microbiological niches are determined by skin thickness, anatomical features of the human body (fossa, pouches, skin folds) and varied distribution of skin appendages which are characterized by their own unique microbiota. They represent the main factors having a key role in the microbiome, hence the species composition of the skin flora across human populations demonstrates a greater degree of similarity between skin sites than between populations [1]. Taking into account the factors listed above, the human body can be divided into high-moisture areas, sebumrich areas and dry areas (fig. 1) [1, 4, 9-12, 15, 23]. Since water is a crucial factor determining bacterial growth, high-moisture skin areas are found to have more numerous commensal microflora than dry skin sites. On the other hand, dry skin is more readily colonized by potentially invasive staphylococci which need a less hydrated environment for their growth - hence frequent skin infections in patients with atopic dermatitis (AD). Other factors influencing bacterial growth are temperature (ranging from $29.5^{\circ} \mathrm{C}$ on the fingers to $36.6^{\circ} \mathrm{C}$ in the axilla) and $\mathrm{pH}$ (from 4.2 on the cheeks to 7.9 in the axilla) [24]. sowe i gruczoły łojowe. Przedstawicielami fizjologicznej mikroflory skóry są $D$. folliculorum (bytujący w mieszkach włosowych) i D. brevis (zasiedlający gruczoły łojowe i gruczoły Meiboma) [20, 21]. Nadmierne rozrastanie się kolonii nużeńców i bakterii z nimi związanych (mikrobiota nużeńców) jest przyczyną nużycy (demodekozy) i prawdopodobnie ma swój udział w etiologii i przebiegu trądziku różowatego (rosacea) [1, 20, 22].

\section{Wirusy}

Izolacja i identyfikacja wirusów obecnych na powierzchni skóry stanowi ciągle wyzwanie. Ze względu na różnorodność wirusów pod względem materiału genetycznego (wirusy DNA i RNA) oraz ich szybką ewolucję utrudnione jest stworzenie bibliotek genomowych. Cząsteczki te nie mają regionów konserwatywnych obecnych w genomach bakterii (16S rRNA) czy grzybów (ITS). Przypuszcza się jednak, że wirusy są nie tylko czynnikiem chorobotwórczym, lecz także odgrywają rolę w utrzymaniu homeostazy skóry [5]. Wykazano, że stanowią one niestały, ale istotny, element mikrobiomu skóry, zwłaszcza wirusy zawierające dwuniciowe DNA (dsDNA), takie jak poliomawirusy (Polyomaviridae) i papillomawirusy (Papillomaviridae) [9, 14].

\section{NISZE MIKROBIOLOGICZNE NA POWIERZCHNI SKÓRY}

Skład jakościowy mikrobiomu człowieka jest specyficzny osobniczo i zróżnicowany ze względu na obszar zasiedlanej skóry. Nisze mikrobiologiczne determinowane są grubością skóry w różnych okolicach, anatomią (doły, zagłębienia i fałdy skóry), a także odmiennym rozkładem przydatków skóry, które charakteryzują się własnym unikatowym mikrobiomem. Są to czynniki podstawowe i kluczowe dla mikrobiomu, dlatego skład gatunkowy flory skóry u ludzi wykazuje wyższe podobieństwo w poszczególnych obszarach niż między poszczególnymi populacjami [1]. Ze względu na wymienione czynniki skórę człowieka można podzielić na obszary o dużej wilgotności, obszary bogate w sebum oraz obszary suche (ryc. 1) [1, 4, 9-12, 15, 23]. Ponieważ woda jest ważnym czynnikiem warunkującym wzrost bakterii, w okolicach o dużej wilgotności notuje się liczniejszą mikroflorę komensalną niż na obszarach suchych. Sucha skóra jest natomiast łatwiej kolonizowana przez potencjalnie inwazyjne gronkowce, które wymagają do wzrostu mniej uwodnionego środowiska, stąd częste zakażenia skóry u osób chorujących na atopowe zapalenie skóry (AZS). Wpływ na wzrost bakterii mają również temperatura (od $29,5^{\circ} \mathrm{C}$ palców rąk do $36,6^{\circ} \mathrm{C}$ dołów pachowych) i pH (od 4,2 na policzkach do 7,9 $\mathrm{w}$ dołach pachowych) [24]. 
Microbiota components dominating in dry areas/Mikrobionty dominujące w obszarach suchych:

- Actinobacteria

- Firmicutes

- Bacteroidetes

- Proteobacteria

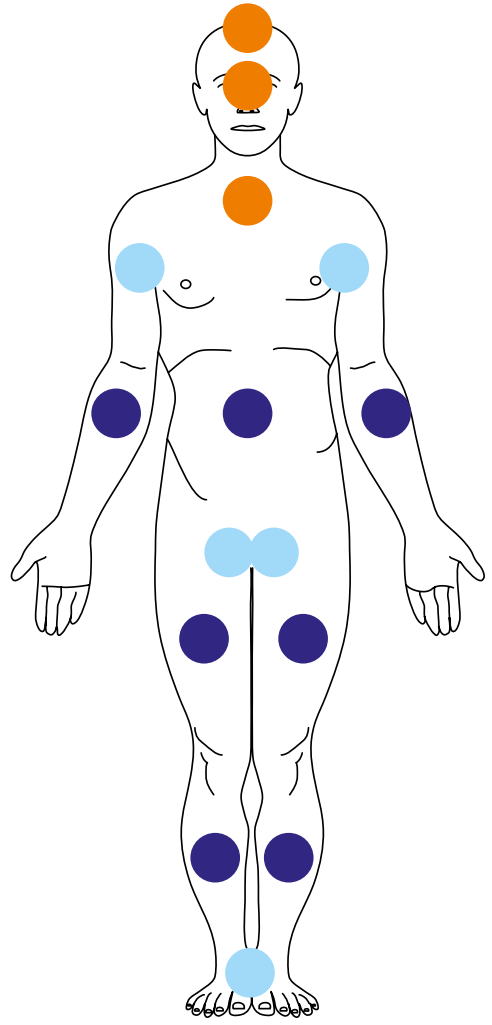

Skin surface types/Na powierzchni skóry wyróżnia się obszary:

High-moisture/Wilgotne

Sebum-rich/Bogate w sebum

Dry/Suche

In addition to bacteria, the foot skin microbiome comprises fungi of the genera/Mikrobiom skóry stóp poza bakteriami obejmuje grzyby z rodzaju: Malassezia, Cryptococccus, Aspergillus, Rhodotorula, Epicoccum, Saccharomyces, Candida, Trichophyton, Microsporum, Epidermophyton

Figure I. Microbial niches on the skin surface

Rycina I. Nisze mikrobiologiczne na powierzchni skóry

\section{ROLE OF SKIN MICROBIOME}

Human symbiotic microflora is involved in metabolic processes, has an effect on the process of tissue maturation in human ontogenesis, and represents an essential element of the body's defence system against pathogenic microorganisms [25].

By colonizing the skin, and thus occupying niches which could be an environment for the growth of pathogens, healthy microbiome protects the body against disease-causing foreign microflora. The process is referred as colonization resistance. The skin itself, by providing a physical barrier and forming a habitat of indigenous microflora, is an integral part of the innate skin immune system, acting as the first line of defence against invading pathogenic microorganisms [4, 26]. Additionally, the skin microbiota (particularly S. epidermidis) inhibits the growth of pathogens through the secretion of AMPs and stimulation of epidermal keratinocytes into their production $[2,4]$.

The effect of the skin microbiome on the functioning of the skin immune system (SIS) is poorly understood. However, skin-resident bacteria are known to have a significant influence on maintaining immune

\section{ROLA MIKROBIOMU SKÓRY}

Mikroflora symbiotyczna człowieka uczestniczy w procesach metabolicznych, wpływa na proces dojrzewania tkanek w rozwoju osobniczym człowieka oraz stanowi istotny element systemu ochrony organizmu przed drobnoustrojami patogennymi [25].

Poprzez zasiedlanie skóry, a także zajmowanie nisz, które mogłyby stanowić środowisko wzrostu patogenów, prawidłowy mikrobiom chroni organizm przed obcą, chorobotwórczą mikroflorą. Proces ten określa się jako odporność na kolonizację (colonisation resistance). Skóra tworząca fizyczną barierę oraz będąca siedliskiem mikroflory autochtonicznej stanowi integralną część wrodzonego układu immunologicznego, tworząc pierwszą linię obrony przed drobnoustrojami patogennymi $[4,26]$. Dodatkowo mikrobiota skóry (zwłaszcza S. epidermidis) hamuje wzrost drobnoustrojów chorobotwórczych poprzez wydzielenie AMPs i stymulowanie keratynocytów naskórka do ich wytwarzania $[2,4]$.

Wpływ mikrobiomu skóry na funkcjonowanie układu odpornościowego (skin immune system - SIS) jest mało poznany. Wiadomo jednak, że bakterie zasiedlające skórę istotnie wpływają na utrzymanie homeostazy układu 
homoeostasis. They modulate innate immune response and affect the development of acquired immune response $[1,2,26]$.

Studies conducted by Naik et al. in mice have shown no difference in the number of lymph nodes and immune cells (skin $\gamma \delta$ T cells, $\alpha \beta$ T cells, eosinophils, mastocytes and dendritic cells) between germ-free (GF) and specific pathogen free (SPF) mice (bred under sterile conditions but having skin microbiome). However, the presence of skin microbiota significantly affects the potential and function of effector T cells in the skin and the course of local inflammation in response to infection. In GF mice $\alpha \beta$ T cells produce considerably less interferon $\gamma($ IFN- $\gamma$ ) and interleukin IL-17A. Smaller quantities of proinflammatory cytokine IL-17A are also secreted by the most primitive skin $\gamma \delta \mathrm{T}$ cells recognizing certain non-protein antigens directly on the surface of microorganisms. The cytokine directly stimulating $\mathrm{T}$ cells in the skin to secrete the mediators discussed is IL-1 - interleukin produced chiefly by monocytes and macrophages in response to contact with microorganisms, other cytokines and fragments of the complement system (C5a). The production of the cytokine has also been shown to be impaired in mice deprived of the skin microbiome. In addition to the effect on the activity of effector T cells, it has been demonstrated that there are significantly more suppressor lymphocytes (Foxp3) residing in the skin of GF mice, which suggests that the skin microbiome regulates the skin immune system and specific response to infection in a complex manner [25].

Besides regulating the expression of proinflammatory cytokines, the skin microbiota also affects the complement system [27]. Chehould et al. in their studies have found that the expression of complement components in GF mice is lower than in mice with commensal skin microflora [28]. The study has also demonstrated that inhibition for the key complement component $\mathrm{C} 5 \mathrm{a}$ in mice with skin microbiome reduces the expression of genes encoding AMPs, pattern recognition receptors (PRR) and proinflammatory factors. The process consequently leads to impaired skin infiltration by immune system cells, and reduces the defensive potential of the skin. The interplay between immune cells and microorganisms at the level of the complement system is interactive in nature. After a 2-week experiment a decrease in microbiome diversity and changes to its composition were noted in mice with a reduced activity of immune system cells resulting from the use of an inhibitor of the C5a receptor (iC5aR) [27].

The process of education of the skin immune system by the skin's bacterial microbiota begins at the moment of birth [2]. Different strains of skin-resident bacteria, varying in their repair potential or resistance to antimicrobial agents etc., have been shown to enter into dif- immunologicznego, modulują wrodzoną odpowiedź immunologiczną i oddziałują na rozwój odpowiedzi nabytej $[1,2,26]$.

W badaniach Naik i wsp. przeprowadzonych na myszach wykazano, że liczba węzłów limfatycznych i komórek układu immunologicznego (skórne limfocyty T $\gamma \delta$, limfocyty T $\alpha \beta$, eozynofile, mastocyty i komórki dendrytyczne) nie różni się u myszy germ-free (GF) i myszy hodowanych w warunkach jałowych, ale posiadających mikrobiom skóry (specific patogen free - SPF). Obecność mikrobiomu skóry istotnie wpływa jednak na potencjał i funkcjonowanie efektorowych limfocytów T w skórze oraz przebieg lokalnego stanu zapalnego w odpowiedzi na zakażenie. U myszy GF limfocyty T $\alpha \beta$ produkują znacznie mniej interferonu $\gamma($ IFN- $\gamma)$ i interleukiny IL-17A. Mniej prozapalne cytokiny IL-17A wydzielają również najbardziej prymitywne, skórne limfocyty $\mathrm{T} \gamma \delta$, rozpoznające pewne niebiałkowe antygeny bezpośrednio na powierzchni drobnoustrojów. Cytokiną bezpośrednio stymulującą limfocyty T w skórze do wydzielania omawianych mediatorów jest IL-1 - interleukina wydzielana głównie przez monocyty i makrofagi w odpowiedzi na kontakt z mikroorganizmami, inne cytokiny oraz fragmenty dopełniacza (C5a). Wykazano, że u myszy pozbawionych mikrobiomu skóry produkcja tej cytokiny również jest upośledzona. Poza wpływem na aktywność efektorowych limfocytów T stwierdzono, że w skórze myszy GF rezyduje istotnie więcej limfocytów supresorowych (Foxp3), co sugeruje, że mikrobiom w złożony sposób reguluje działanie skórnego układu immunologicznego i swoistą odpowiedź na zakażenie [25].

Poza regulacją ekspresji cytokin prozapalnych mikrobiom skóry wpływa także na układ dopełniacza [27]. Chehould i wsp. w swoich badaniach wykazali, że u myszy GF ekspresja składników dopełniacza jest niższa niż u myszy z komensalną mikroflorą skóry [28]. W badaniach stwierdzono także, że blokowanie receptora dla kluczowego składnika dopełniacza C5a u myszy z mikrobiomem skóry powoduje zmniejszoną ekspresję genów kodujących AMPs, receptorów rozpoznających wzorce (pattern recognition receptors - PRR) i czynników prozapalnych. W konsekwencji prowadzi do upośledzenia infiltracji skóry przez komórki układu immunologicznego i obniżenia potencjału obronnego skóry. Oddziaływanie komórek układu immunologicznego z drobnoustrojami na poziomie układu dopełniacza ma charakter interaktywny. U myszy, u których obniżono aktywność komórek układu immunologicznego poprzez zastosowanie inhibitora receptora $\mathrm{C} 5 \mathrm{aR}$ (iC5aR), po 2 tygodniach eksperymentu zaobserwowano zmniejszenie różnorodności mikrobiomu i zmiany w jego składzie [27].

Proces edukacji układu immunologicznego skóry przez mikrobiom bakteryjny skóry rozpoczyna się od chwili przyjścia człowieka na świat [2]. Wykazano, że poszczególne szczepy bakterii zasiedlających skórę, różniące się m.in. potencjałem naprawczym lub odporno- 
ferent interactions with other microorganisms and host cells. Depending on these interactions, the skin immune system acquires different characteristics (expression of receptors, enzymes, etc.) $[2,26]$. It is currently known that genetic predispositions and metabolic diseases, by affecting the continuity of the epidermal barrier and the availability of nutrients, are capable of influencing the amount and composition of the skin microbiome and thus its interactions with immune system cells. The loss of control over the immune system in response to microbiota and environmental antigens present on the skin surface is implicated as a key factor in the development of allergies and inflammatory and autoimmune skin diseases [2, 14, 25, 26, 28].

\section{Effect of fungi on skin function}

The mechanism of interactions between fungi and cells of the skin and the immune system has not been fully explained yet. It has been suggested that fungi and their products, similarly to bacteria, are able to communicate with cells via toll-like receptors (TLR). Fungi of the genus Malassezia and their products have been demonstrated to stimulate the production of cytokines (including chemokines), adhesion molecules and antimicrobial compounds in keratinocytes, antigen-presenting dendritic cells, macrophages, eosinophils and neutrophils $[15,16]$.

In addition to affecting skin cells, Malassezia spp. fungi release a variety of metabolites which have an effect on the number and species within its genus as well as other microorganisms making up the skin microbiome. Malassezia furfur is known to be the most effective inhibitor of the growth of other fungi. At the same time, the fungus is resistant to substances secreted by other Malassezia species [29].

Disturbances of the fungal living environment (e.g. $\mathrm{pH}$ changes on the skin surface), together with impact on fungal number and species composition, are reflected in the functioning of the skin. Possible consequences include increased production of certain proinflammatory cytokines and exacerbation of symptoms accompanying inflammatory skin diseases (AD, seborrhoeic dermatitis, psoriasis) or attenuation of the activity of immune system cells through the production of indole compounds (pityriasis versicolor) $[15,16]$. The course of inflammation in the skin is also determined by irritant and sensitizing substances produced by Malassezia spp. Importantly, they vary across different Malassezia species. Consequently, the course of inflammation within affected sites may depend on the fungal species composition [17].

\section{Effect of Demodex on skin function}

Similarly to other microorganisms residing on the skin surface, Demodex mites have an effect on skin ścią na działanie czynników przeciwdrobnoustrojowych, wchodzą w odmienne interakcje $\mathrm{z}$ innymi drobnoustrojami oraz komórkami gospodarza. Skutkiem tych interakcji jest różnokształtny obraz układu immunologicznego skóry (ekspresja receptorów, enzymów itp.) [2, 26]. Aktualnie wiadomo, że predyspozycje genetyczne i choroby metaboliczne poprzez zmianę w szczelności bariery naskórkowej i dostępność składników odżywczych mogą wpływać na liczebność i skład mikrobiomu, a także jego interakcje z komórkami układu immunologicznego. Utrata kontroli nad układem immunologicznym w odpowiedzi na obecność na powierzchni skóry mikrobiontów i antygenów środowiskowych jest ważnym czynnikiem w alergii oraz skórnych chorób o podłożu zapalnym i autoimmunologicznym [2, 14, 25, 26, 28].

\section{Wpływ grzybów na funkcjonowanie skóry}

Mechanizm oddziaływania między grzybami a komórkami skóry i układu immunologicznego nie został w pełni poznany. Sugeruje się, że podobnie jak bakterie, grzyby i ich produkty mogą komunikować się z komórkami poprzez receptory TLR (Toll-like receptors). Wykazano, że grzyby z rodzaju Malassezia i ich produkty pobudzają produkcję cytokin (w tym chemokin), cząsteczek adhezyjnych i związków o działaniu przeciwdrobnoustrojowym w keratynocytach, komórkach dendrytycznych prezentujących antygen, makrofagach, eozynofilach i neutrofilach $[15,16]$.

Grzyby Malassezia spp. poza wpływem na komórki skóry poprzez uwalnianie różnych metabolitów oddziałują na skład liczebny i gatunkowy w obrębie swojego rodzaju oraz innych mikroorganizmów stanowiących mikrobiom skóry. Najefektywniej wzrost innych grzybów hamuje M. furfur. Grzyb ten jednocześnie jest najbardziej oporny na działanie substancji wydzielanych przez inne gatunki Malassezia [29].

Zaburzenie środowiska bytowania grzybów (np. pH na powierzchni skóry), a także wpływ na ich liczebność i skład gatunkowy ma odzwierciedlenie w funkcjonowaniu skóry. Skutkiem może być zwiększona produkcja określonych cytokin prozapalnych i nasilenie objawów skórnych chorób zapalnych (AZS, łojotokowe zapalenie skóry, łuszczyca) lub wyciszenie aktywności komórek układu immunologicznego poprzez produkcję związków indolowych (łupież pstry) [15, 16]. Na przebieg stanu zapalnego w obrębie skóry mają także wpływ czynniki drażniące i alergizujące produkowane przez Malassezia spp. Co ważne, różnią się one między poszczególnymi gatunkami Malassezia. Dlatego przebieg stanu zapalnego w obrębie zmian chorobowych może zależeć od składu gatunkowego omawianych grzybów [17].

\section{Wpływ nużeńców na funkcjonowanie skóry}

Nużeńce, podobnie jak inne drobnoustroje bytujące na powierzchni skóry, wpływają na jej fizjolo- 
physiology by modulating cell activity. The fact that serum IgD, $\alpha 1$-antitrypsin and $\alpha 1$-antichymotrypsin have been identified on the surface of Demodex mites is evidence that these microorganisms are recognized by the skin immune system [30]. It has also been shown that chitin, that builds Demodex skeletons, can be bound by TRL2 and, via this pathway, induce the secretion of proinflammatory cytokines from keratinocytes. Demodex mites exert an indirect influence on skin function as well. While dying, these organisms release into the skin appendages parts of walls of the bacteria that made up their microbiome. They represent another immunomodulatory factor [22].

\section{Factors affecting skin microbiome}

Metagenomic analysis performed to gain an indepth knowledge of the human microbiome reveals a high diversity of bacterial strains inhabiting the skin across different human populations and variation in bacterial species in terms of locations of colonized niches. The microbiome is currently known to evolve and change in response to age, sex, ethnic group, climate, UV exposure, working and living environment, lifestyle (diet, hygienic and cosmetic habits), type of clothing, sports activities, consumption of alcohol and other stimulants, etc.), stress and drugs therapies. Interestingly, even lateralization determining right and left hand functionality is a factor impacting the composition of species in the hand microbiota (fig. 2) $[2,4,5,11,14,23,31]$. gię poprzez modulowanie aktywności komórek. Na powierzchni nużeńców wykryto surowiczą $\operatorname{IgD}, \alpha 1-$ -antytrypsynę i $\alpha 1$-antychymotrypsynę, co wskazuje, że nużeńce są rozpoznawane przez układ immunologiczny skóry [30]. Wykazano także, że chityna stanowiąca budulec szkieletu nużeńców może być wiązana przez receptory TRL2 i na tej drodze indukować wydzielanie z keratynocytów cytokin prozapalnych. Wpływ nużeńców na funkcjonowanie skóry ma również charakter pośredni. Roztocza te, umierając, uwalniają do przydatków skóry elementy ścian bakterii, które stanowiły ich mikrobiom. Stanowią one dodatkowy czynnik immunomodulujący [22].

\section{Czynniki wpływające na mikrobiom skóry}

Analiza metagenomiczna zastosowana w celu dogłębnego poznania mikrobiomu człowieka wskazuje na dużą różnorodność szczepów bakterii zasiedlających skórę w obrębie odrębnych populacji ludzkich oraz zróżnicowanie gatunkowe bakterii pod względem lokalizacji zasiedlanej niszy. Aktualnie wiadomo, że mikrobiom podlega rozwojowi i zmianom w zależności od wieku, płci, grupy etnicznej, klimatu i ekspozycji na promieniowanie UV, środowiska życia i pracy, stylu życia (dieta, zwyczaje higieniczne i kosmetyczne, rodzaj noszonej odzieży, uprawiane sporty, alkohol i inne używki itd.), stresu i stosowanych leków. Czynnikiem, który wpływa na skład gatunkowy mikrobiomu dłoni, jest nawet lateralizacja oddziałująca na funkcjonalność prawej i lewej ręki (ryc. 2) [2, 4, 5, 11, 14, 23, 31].

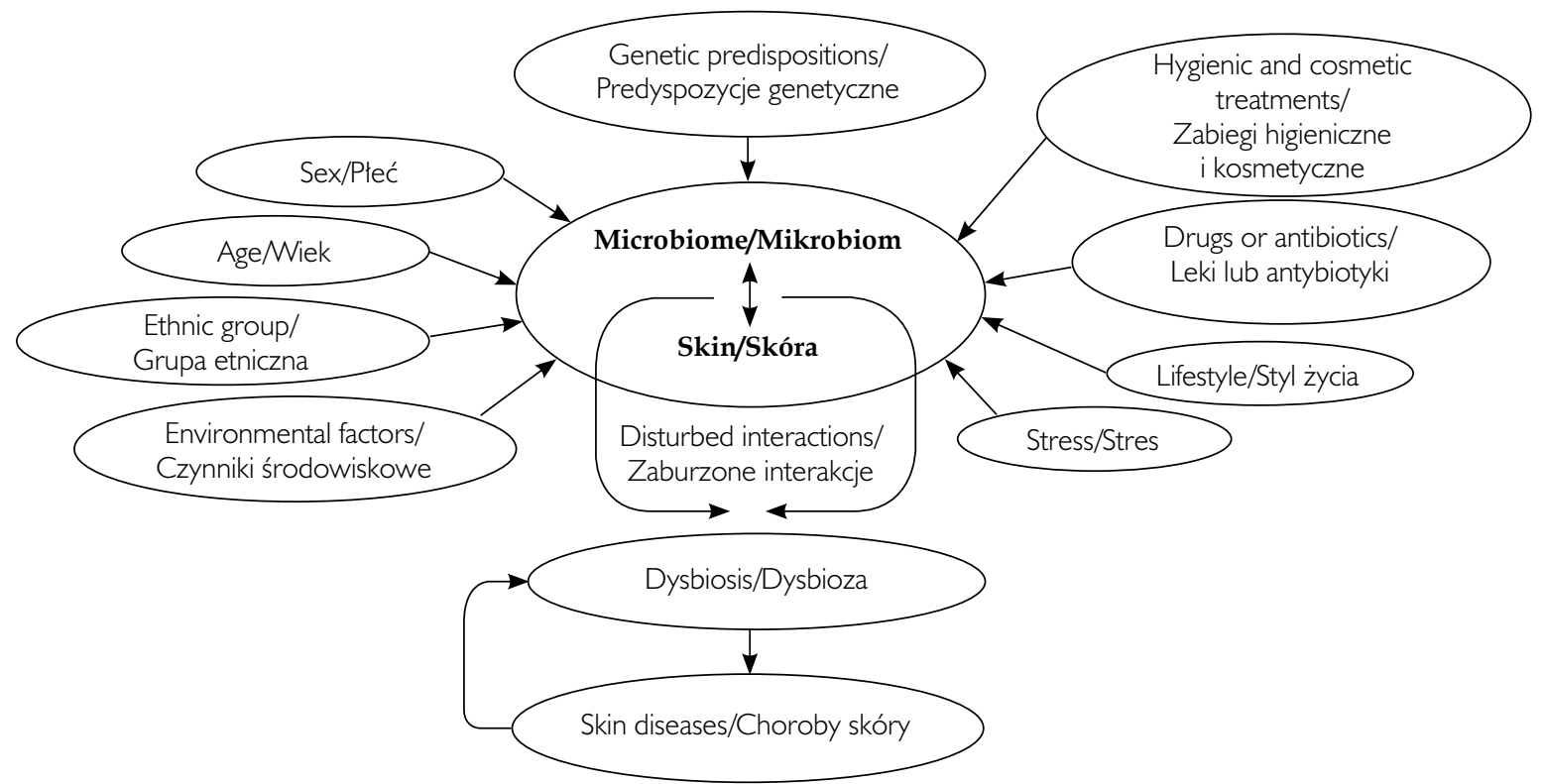

Figure 2. Factors affecting the skin microbiome. Disturbance of interactions within the microbiome and between the skin and microbiome leads to dysbiosis promoting skin diseases

Rycina 2. Czynniki wpływające na mikrobiom skóry. Zaburzenie interakcji w obrębie mikrobiomu oraz między skórą i mikrobiomem prowadzi do dysbiozy, która sprzyja rozwojowi chorób skóry 
Skin colonization by microorganisms starts already at birth. It is a gradual process affected to a considerable extent by the mode of delivery. The skin of vaginally delivered neonates is colonized by maternal microflora (Lactobacillus spp., Prevotella spp., Sneathia spp.) while passing through the vaginal canal. The need to perform a caesarean section exposes the skin of the newborn from the very beginning to microorganisms residing on the skin of the mother and medical personnel, and microflora present at the hospital environment. As a result, the skin of the neonate is colonized by completely different bacterial species (Staphylococcus spp., Corynebacterium spp., Propionibacterium spp.) [32].

The process of fungal colonization of the skin is equally dynamic. Fungi of the genus Malassezia are detectable on the skin surface already on the first day of life in $89-100 \%$ of neonates [18].

Demodex also get on the skin of newborns through physical contact, however no colonization takes place, probably because of low sebum levels on the skin surface. The presence of Demodex is not diagnosed on the skin until adulthood, and the prevalence rises with age, with more men affected than women [20].

The greatest diversity of species is found on the skin of children at the age under 3 years. During this period, the microbiota evolves in response to changes in skin physiology and diet, and different stages of motor development increasing the number of locations visited by the child [1]. The skin of young children is colonized primarily by bacteria of the genus Streptococcus and of the type Proteobacteria (Betaproteobacteria and Gammaproteobacteria). However, some of the bacteria residing on children's skin do not occur in adults. Instead, lipophilic bacteria Propionibacterium spp. and Corynebacterium spp. are found [2].

In adult individuals the "basic" composition of the skin microbiome is determined mostly by anatomical and physiological factors, hence there are differences in the skin microbiome between women and men. Major factors impacting the growth of microorganisms on the surface of the skin include the amount and composition of sebum and sweat. The effect of the hormone system on the skin microbiota is the most pronounced during puberty, and in women during pregnancy and menopause. An increase in androgen activity in adolescents leads to elevated activity of sebaceous glands which are a habitat for $P$. acnes. The bacteria, by hydrolyzing sebum triglycerides to free fatty acids, take part in the formation of the skin's protective hydrolipid film [1]. However, excessive growth of $P$. acnes contributes to the development of acne vulgaris [24].

In the elderly population the skin microbiota undergoes changes affecting both the count of microorganisms on the skin surface and their diversity. One
Zasiedlanie skóry przez drobnoustroje zaczyna się już w trakcie porodu i jest procesem stopniowym, na przebieg którego istotnie wpływa rodzaj porodu. Skóra dzieci urodzonych siłami natury zasiedlana jest mikroflorą matki w czasie przechodzenia przez kanał rodny (Lactobacillus spp., Prevotella spp., Sneathia spp.). Konieczność wykonania cesarskiego cięcia powoduje, że skóra noworodka jest zasiedlana od samego początku przez drobnoustroje bytujące na skórze matki, personelu medycznego oraz mikroflorę szpitalną. Skład gatunkowy bakterii kolonizujących noworodka jest diametralnie inny (Staphylococcus spp., Corynebacterium spp., Propionibacterium spp.) [32].

Kolonizacja skóry przez grzyby jest procesem równie dynamicznym. Już w pierwszej dobie życia u $89-100 \%$ noworodków można wykryć na powierzchni skóry grzyby z rodzaju Malassezia [18].

Nużeńce poprzez kontakt fizyczny dostają się na skórę noworodków, jednak jej nie kolonizują, prawdopodobnie ze względu na niski poziom sebum na jej powierzchni. Obecność nużeńców diagnozowana jest dopiero u ludzi dorosłych, a częstość ich występowania wzrasta $\mathrm{z}$ wiekiem $\mathrm{i}$ jest wyższa u mężczyzn niż u kobiet [20].

Skóra dzieci do ok. 3. roku życia charakteryzuje się największą różnorodnością gatunkową. W tym czasie mikrobiom ewoluuje pod wpływem zmian w fizjologii skóry, zmian w diecie, etapów rozwoju ruchowego, a także zwiększania się liczby miejsc, w których przebywa dziecko [1]. Wykazano, że skóra małych dzieci zasiedlona jest głównie przez bakterie z rodzaju Streptococcus i bakterie typu Proteobacteria (Betaproteobacteria i Gammaproteobacteria). U dorosłych natomiast część z bakterii zasiedlających skórę dzieci nie występuje, pojawiają się natomiast bakterie lipofilne - Propionibacterium spp. i Corynebacterium spp. [2].

U osób dorosłych wpływ na "podstawowy" skład gatunkowy mikrobiomu skóry mają głównie uwarunkowania anatomiczne i fizjologiczne, dlatego mikrobiom skóry kobiet różni się od mikrobiomu mężczyzn. Istotnymi czynnikami warunkującymi wzrost drobnoustrojów na powierzchni skóry są ilość i skład produkowanego łoju i potu. Wpływ układu hormonalnego na mikrobiotę skóry najbardziej widoczny jest w okresie pokwitania oraz u kobiet w okresie ciąży i menopauzy. U nastolatków wzrost aktywności androgenów powoduje zwiększoną aktywność gruczołów łojowych stanowiących siedlisko dla bakterii $P$. acnes. Bakterie te poprzez hydrolizowanie obecnych w sebum trójglicerydów do wolnych kwasów tłuszczowych uczestniczą $\mathrm{w}$ formowaniu ochronnego płaszcza hydrolipidowego skóry [1]. Nadmierny wzrost $P$. acnes przyczynia się jednak do rozwoju trądziku pospolitego [24].

Mikrobiom zasiedlający skórę zmienia się u osób starszych. Wykazano, że zmiany te dotyczą zarówno liczby drobnoustrojów na powierzchni skóry, jak i ich 
of the factors contributing to changes in the microbiological profile in the elderly is decreased sweat gland activity which makes the skin dry. On account of decreased keratinocyte transit time through the epidermis, and hence longer persistence of the keratinized epidermal layer on the skin surface, together with a decrease in the activity of the skin immune system, the skin of the elderly is inhabited by yeasts and dermatophytes more commonly than the skin of young people [1, 4, 18, 31].

Factors such as diseases, fever, antibiotic therapy, stress or injury induce rapid but temporary microbiome changes. When the triggering factor disappears, the microbiome returns to its "baseline" state [1]. An analysis of genetic material at the strain level has shown the microbiome composition to be relatively invariable in time despite the activity of internal and environmental factors. Therefore, microbiome stability is determined by the ability of different strains to persist on the skin surface rather than the process of continuous skin colonization by microorganisms present in the human environment. Importantly, the nature and extent of resistance to changes are largely individual traits [9].

\section{Healthy skin microbiome}

The discussion of skin microbiome would be incomplete without addressing the important issue of normal ("healthy") skin microbiome A wide-scale meta-analysis of the microbiomes of healthy individuals and patients has shown that, similarly to the lower section of the digestive system, "healthy skin microbiome" is characterized by high diversity of species and equilibrium in the quantitative ratios between different microorganisms. Studies have also confirmed that dysbiosis, i.e. imbalance in the skin microbiome, impairs the barrier functions performed by the skin and constitutes one of the aetiological factors of skin diseases [2, 26, 33, 34]. The correlation has been demonstrated, among other conditions, for acne vulgaris, rosacea, psoriasis and seborrhoeic dermatitis [2, 33, 34]. Also, reduced diversity of species among skin-resident microorganisms is an important problem in patients with diabetes and AD $[34,35]$.

In view of the significance of microbiological biodiversity for maintaining homoeostasis of the skin and entire body, it is necessary to summarize the results of the meta-analysis referred above, examining the impact of the Western lifestyle on the skin microbiome. The metaanalysis has found that, similarly to the gut microflora, the skin microflora in populations living in industrialized countries is much less diverse than in primitive communities. Major factors adversely affecting the diversity of microorganisms on the skin surface include not only widespread różnorodności. Jednym z czynników wpływających na zmianę profilu mikrobiologicznego u ludzi starszych jest zmniejszenie aktywności gruczołów potowych, co powoduje, że skóra staje się sucha. Ze względu na spowolnienie przejścia keratynocytów w naskórku oraz zmniejszenie aktywności skórnego układu immunologicznego skóra seniorów częściej niż osób młodych zasiedlana jest przez drożdżaki i dermatofity $[1,4,18,31]$.

Takie czynniki, jak choroby, gorączka, antybiotykoterapia, stres czy obrażenia, powodują gwałtowne, ale czasowe zmiany w mikrobiomie. Po wygaśnięciu czynnika indukującego zmiany mikrobiom wraca do stanu określanego jako „podstawowy” [1]. Analiza materiału genetycznego na poziomie szczepów wykazała, że skład mikrobiomu jest stosunkowo niezmienny w czasie, pomimo działania czynników wewnętrznych i środowiskowych. Stabilność mikrobiomu wynika więc ze zdolności utrzymania się poszczególnych szczepów na powierzchni skóry, a nie z ciągłego zasiedlania skóry przez drobnoustroje pochodzące $z$ otoczenia człowieka. Co ważne, charakter i poziom odporności na zmiany są cechami w dużym stopniu indywidualnymi [9].

\section{Prawidłowy mikrobiom skóry}

W rozważaniach dotyczących mikrobiomu skóry istotna jest odpowiedź na pytanie o prawidłowy, "zdrowy" mikrobiom skóry. Przeprowadzona na szeroką skalę metaanaliza danych dotyczących mikrobiomów ludzi zdrowych i chorych wykazała, że podobnie jak w przypadku dolnego odcinka układu pokarmowego „mikrobiom zdrowej skóry” to mikrobiom charakteryzujący się dużą różnorodnością gatunkową i równowagą w stosunku liczby poszczególnych drobnoustrojów. Wyniki badania potwierdziły także, że dysbioza, czyli zaburzenie równowagi w mikrobiomie skóry, prowadzi do obniżenia funkcji barierowych skóry i jest jednym z czynników etiologicznych chorób skóry [2, 26, 33, 34]. Zależność taką wykazano m.in. w przypadku trądziku pospolitego, trądziku różowatego, łuszczycy i łojotokowego zapalenia skóry [2, 33, 34]. Zmniejszona różnorodność gatunkowa w obrębie drobnoustrojów zasiedlających skórę jest natomiast istotnym problemem $u$ chorych na cukrzycę i AZS $[34,35]$.

W związku z istotnością bioróżnorodności mikrobiologicznej w utrzymaniu homeostazy skóry i całego organizmu konieczne jest przytoczenie wyników cytowanej metaanalizy dotyczących wpływu zachodniego stylu życia na mikrobiom skóry. Wykazano, że podobnie jak w przypadku mikroflory jelit mikroflora skóry osób żyjących w krajach uprzemysłowionych jest dużo mniej zróżnicowana niż ludzi w społecznościach mniej rozwiniętych. Istotnymi czynnikami negatywnie wpływającymi na różnorodność mikroorganizmów na powierzchni skóry są nie tylko powszechnie stosowane antybiotyki, lecz także 
antibiotic use but also hygienic and cosmetic treatments performed using chemical substances. Such agents constantly remove the skin microflora, and consequent changes in the physicochemical conditions on the surface of the skin make it more difficult for commensal microflora to recolonize the skin, at the same time creating favourable conditions for skin colonization by pathogens [14, 34-36]. A simple step of eliminating the use of basic cosmetics such as shampoo and deodorant increases the diversity of the skin microbiome during a short period (a few days) [11].

\section{CONCLUSIONS}

The knowledge of skin microbiome and its role in the healthy functioning of the skin has expanded thanks to the introduction of molecular methods. It has been shown that it is not possible to develop a uniform profile of the skin microbiome, as it is affected by both internal and external factors. However, it is known that a significant role in normal functioning of the skin microbiome must be attributed to its diversity and appropriate quantitative ratios between different microorganism groups. Dysbiosis represents a significant aetiological factor in a number of skin diseases. The typical lifestyle of the Western world - with intensive use of hygienic and cosmetic treatments - is a factor negatively affecting microbiome diversity.

\section{CONFLICT OF INTEREST}

The authors declare no conflict of interest. zabiegi higieniczne i kosmetyczne z wykorzystaniem substancji chemicznych. Powodują one nieustanne usuwanie ze skóry mikroflory, a zmiana warunków fizykochemicznych na powierzchni skóry utrudnia jej rekolonizację przez florę komensalną i jednocześnie stwarza warunki do jej kolonizacji przez patogeny [14, 34-36]. Proste wykluczenie podstawowych kosmetyków, takich jak szampon i dezodorant, powoduje w krótkim czasie (kilka dni) wzrost zróżnicowania mikrobiomu skóry [11].

\section{PODSUMOWANIE}

Wprowadzenie metod molekularnych pozwoliło na poszerzenie wiedzy na temat mikrobiomu skóry i jego roli w prawidłowym funkcjonowaniu skóry. Wykazano, że nie można opracować jednolitego profilu mikrobiomu skóry, ponieważ podlega on wpływowi czynników wewnętrznych i zewnętrznych. Wiadomo natomiast, że istotnym czynnikiem w prawidłowym funkcjonowaniu mikrobiomu skóry jest jego różnorodność i odpowiedni stosunek liczby poszczególnych grup drobnoustrojów. Dysbioza stanowi ważny czynnik etiologiczny wielu chorób skóry, a zachodni tryb życia z intensywnie stosowanymi zabiegami higienicznymi i kosmetycznymi jest czynnikiem negatywnie wpływającym na różnorodność mikrobiomu.

\section{KONFLIKT INTERESÓW}

Autorzy nie zgłaszają konfliktu interesów.

\section{References \\ Piśmiennictwo}

1. Grice E.A., Serge J.A.: The skin microbiome. Nat Rev Microbiol 2011, 9, 244-253.

2. Belkaid Y., Hand T.: Role of microbiota in immunity and inflammation. Cell 2014, 157, 121-141.

3. Malinowska M., Tokarz-Deptuła B., Deptuła W.: Mikrobiom człowieka. Post Mikrobiol 2017, 56, 33-42.

4.Percival S.L., Emanuel C., Cutting K.F., Williams D.W.: Microbiology of the skin and the role of biofilms in infections. Int Wound J 2012, 9, 14-32.

5. Kong H.H.: Skin microbiome: genomics-based insights into the diversity and role of skin microbes. Trends Mol Med 2011, 17, 320-328.

6. Kong H.H., Andersson B., Cavel T., Common J.E., Jackson A.S., Olson A.D., et al.: Performing skin microbiome research: a method to the madness. J Invest Dermatol 2017, 137, 561-568.

7. Rieg S., Garbe C., Sauer B., Kalbacher H., Schittek B.: Dermcidin is constitutively produced by eccrine sweat glands and is not induced in epidermal cells under inflammatory skin conditions. Br J Dermatol 2004, 151, 534-539.

8. Micali G., Lacarrubba F., Bongu A., West D.P.: The skin barrier. [In:] The Biology of the Skin. R.K. Freinkel, D.T. Woodley (eds.), The Parthenon Publishing Inc., New York, London, 2001, 219-231.

9. Oh J., Byrd A.L., Park M., Kong H.H., Segre J.A.: Temporal stability of the human skin microbiome. Cell 2016, 165, 854-866.

10. Rahim K., Saleha S., Zhu X., Huo L., Basit A., Franco O.L.: Bacterial contribution in chronicity of wounds. Microb Ecol 2017, 73, 710-721.

11. Findley K., Oh J., Yang J., Conlan S., Deming C., Meyer J.A., et al.: Topographical diversity of fungal and bacterial communities in human skin. Nature 2013, 498, 367-370. 
12. Perez Perez G.I., Gao Z., Jourdain R., Ramires J., Gany F., Clavaund C., et al.: Body site is a more determinant factor than human population diversity in the healthy skin microbiome. PloS One 2016, 11, e0151990.

13. Grice E.A., Kong H.H., Conlan S., Deming C.B., Davis J., Young A.C., et al.: Topographical and temporal diversity of the human skin microbiome. Science 2009, 324, 1190-1192.

14. Reid G., Younes J.A., Van der Mei H.C., Gloor G.B., Knight R., Busscher H.J.: Microbiota restoration: natural and supplemented recovery of human microbial communities. Nat Rev Microbiol 2011, 9, 27-38.

15. Schoemmer N.N., Gallo R.L.: Structure and function of the human skin microbiome. Trends Microbial 2013, 21, 660-668.

16. Gaitanis G., Magiatis P., Hantschke M., Bassukas I.D., Velegraki A.: The Malassezia genus in skin and systemic diseases. Clin Microbiol Rev 2012, 25, 106-141.

17. Glatz M., Bosshard P.P., Hoetzencker W., Schmid-Grendelmeier P.: The role of Malassezia spp. in atopic dermatitis. J Clin Med 2015, 4, 1217-1228.

18. Jagielski T., Rup E., Macura A.B., Bielecki J.: Charakterystyka grzybów z rodzaju Malassezia. I Aspekty mikrobiologiczne i immunologiczne. Post Mikrobiol 2013, 52, 295-305.

19. Prohic A., Sadicovic T.J., Krupalija-Fazlic M., Kuskunovic-Vlahovljak S.: Malassezia species in healthy skin and in dermatological conditions. Int J Dermatol 2016, 55, 494-504.

20. Du Vivier A.: Atlas dermatologii klinicznej. Elsevier Urban \& Partner, Wrocław, 2005.

21. Bikowski J.B., Del Rosso F., Del Rosso J.Q.: Demodex dermatitis. A retrospective analysis of clinical diagnosis and successful treatment with topical crotamiton. Clin Aesth Dermatol 2009, 2, 20-25.

22. Jarmuda S., Adamski Z., Żaba R.: Potential role of Demodex mites and bacteria in the induction of rosacea. J Med Microbiol 2012, 61, 1504-1510.

23. Dréno B., Araviiskaia E., Berardesca E., Gontijo G., Sanchez Viera M., Xiang L.F., et al.: Microbiome in healthy skin, update for dermatologists. J Eur Acad Derm Venereol 2016, 30, 2038-2047.

24. Murillo N., Aubert J., Raoult D.: Microbiota of Demodex mites from rosacea patients and controls. Microb Pathog 2014, 71-72, 37-40.

25. Michalak-Stoma A., Chodorowska G., Juszkiewicz-Borowiec M., Gerkowicz A., Bartosińska J.: Rola Propionibacterium acnes (P. acnes) w patogenezie trądziku pospolitego. Nowa Medycyna 2010, 2, 56-59.

26. Naik S., Bouladoux N., Wilhelm C., Molloy M.J., Salcedo R., Kasrenmuller W., et al.: Compartmentalized control of skin immunity by resident commensals. Science 2012, 337, 1115-1119.

27. Belkaid Y., Serge J.S.: Dialogue between skin mikrobiota and immunity. Science 2014, 21, 954-959.

28. Chehould C., Rafail S., Tyldsley A.S., Seykora J.T., Lambris J.D., Grice E.A.: Complement modulates the cutaneous microbiome and inflammatory milieu. Proc Natl Acad Sci U S A 2013, 110, 15061-15066.

29. Lee Y.K., Mazmanian S.K.: Has the microbiota played a critical role in the evolution of the adaptive immune system? Science 2010, 330, 1768-1773.

30. Arzumanian V.G., Sergeev A.Y., Shelemekh O.V., Ojovan I.M., Serdiuk O.A.: Antagonistic activity of Malassezia spp. towards other clinically significant yeast genera. Bull Exp Biol Med 2009, 148, 410-415.

31. Tsutsumi Y.: Deposition of IgD, alpha-1-antitrypsin and alpha-1-antichymotrypsin on Demodex folliculorum and D. brevis infesting the pilosebaceous unit. Pathol Int 2004, 54, 32-34.

32. Li W., Han L., Yu P., Ma C., Wu X., Xu J.: Nested PCR-denaturing gradient gel electrophoresis analysis of human skin microbial diversity with age. Microbial Res 2014, 169, 686-692.

33. Dominguez-Bello M.G., Costello E.K., Contrereas M., Magris M., Hidalgo G., Fierer N., et al.: Delivery mode shapes the acquisition and structure of the initial microbiota across multiple body habitats in newborns. Proc Natl Acad Sci U S A 2010, 107, 11971-11975.

34. Weyrich L.S., Dixit S., Farrer A.G., Cooper A.J., Cooper A.J.: The skin microbiome: associations between altered microbial communities and disease. Australas J Dermatol 2015, 56, 268-274.

35. Wallen-Russell C., Wallen-Russell S.: Meta-analysis of skin microbiome: new link between skin microbiota diversity and skin health with proposal to use this as future mechanism to determine whether cosmetics products damage the skin. Cosmetics 2017, 4, 14 .

36. Baldwin H.E., Bhatia N.D., Friedman A., Martin Eng R., Seité S.: The role of cutaneous microbiota harmony in maintaining a functional skin barrier. J Drugs Dermatol 2017, 16, 12-18.

Received: 27.09 .2017

Accepted: 28.01.2018

Otrzymano: 27.09.2017 r.

Zaakceptowano: 28.01.2018 r.

How to cite this article

Adamczyk K., Garncarczyk A.A., Antończak P.P.: The microbiome of the skin. Dermatol Rev/Przegl Dermatol 2018, $105,285-297$.

DOI: https://doi.org/10.5114/dr.2018.75584. 